\title{
FOR THE ART OF DISTANCE
}

\section{TOMASZ RAKOWSKI, PRZEPŁYWY, WSPÓŁDZIAŁANIA, KRĘGI MOŻLIWEGO. ANTROPOLOGIA POWODZENIA}

\author{
Aleksandra Bilewicz \\ Polish Academy of Sciences
}

Przeplywy, wspótdziatania, kregi mo:ilinego [Inflows, cooperation, the realm of the possible] is Tomasz Rakowski's research record of his stay in the northern-Mongolian town and territorial unit, or sum, of Bulgan, which is inhabited by people belonging to the Torghut group or tribe. The Torghuts are a branch of the larger Oirat group, a minority in a country dominated by the Khalkha group. The small town of Bulgan, with around 11,000 inhabitants, turns out to be a business and cultural centre, pulsing with life and linked by strong ties with other cities, including the capital of Mongolia, Ulan Bator, as well as with centres for Mongolian business activities in China, especially Sinciang.

The book introduces us to a society in the process of intense transformation from a traditional pastoral economy - requiring a nomadic way of life with moves between summer and winter pastures - to a capitalist economy, in which traditional herding has begun to play a lesser role. This rapid change is happening amidst the rubble of the communist system, which altered the traditional economy based on nomadic animal husbandry but also in some ways preserved it. Rakowski's work is part of the stream of research conducted in this region by Polish ethnologists. His visit, in the company of Lech Mróz and Oungerel Tangad, is a new exploration of an area that Polish researchers (Sławoj Szynkiewicz, Lech Mróz, and Jerzy Wasilewski) visited forty years ago. 
Rakowski's book is an attempt to portray a society in movement and developing rapidly - with variable success - in a manner characterised by the fact that its expanding business activities are deeply rooted in local kinship structures while being simultaneously and variously intertwined with the state. Development in Bulgan is happening largely thanks to actions in the informal sphere. Rakowski attempts to grasp what is informal and transitory in the situation by drawing on the idea of "instant history," or history that is "still happening" (2018: 92) and thus can be grasped through the observations of participants and through oral reports. Rakowski's tale of the contemporary inhabitants of Bulgan reads like a kind of "live transmission." As he shows, grasping the informal dimension has great importance in a situation where the official documents created by the Mongol authorities are written in a propaganda manner and do not have much in common with what is really pursued. It would also seem that such a manner of researching and presenting materials is connected with the author's more general view of the nature of what is social and what takes place in action, in the process of "humanifying" (Rakowski refers to Tim Ingold's idea; 2018: 157). Thus there is a dimension that is in continual movement and that cannot, in his opinion, be sufficiently described in terms of closed, lasting, or reproducing structures.

Rakowski uses various terms to describe the essence of the process of endogenous growth; he speaks of an "art of the informal," of collective business, of "brothering" and "sistering," of sharing success. He refers also to a metaphor which was repeatedly used by his research subjects and which is rooted in the Mongol tradition. The metaphor concerns individual success that can spread its rays to others. Thus there is talk of a life force (sïld), or of the force of the "wind steed" (chijmor). The nature of this specific force is perhaps best described in Rakowski's story of a crowd of men who surround the winner of a traditional horse race in order to bathe their hands in the animal's sweat and take to themselves a part of its lifegiving force. The new generation of Torghut businessmen are said to be in possession of this force, and their vigorous, fluent, and variable activities - which are characterised by continual movement between Bulgan, Ulan Bator, and often border territories in China - are changing the region. The businessmen invest part of their earnings in the region's development and social life. They have co-financed, for instance, the equipment for a local preschool, the construction of roads, and religious and sports celebrations. Thus they also contribute to strengthening and celebrating the local identity. Both the purely economic activities and the activities that are focused 
on the integration of local society occur thanks to the close ties of the Torghut community. On the one hand, these are family ties (a large expanded family supporting its members, e.g., by sending members to study in the city), and on the other hand, they are the ties of a peer group. Rakowski stresses the large role of lasting friendship and cooperation between people from one school class. It is school colleagues who have founded a club to care for nutag - the place of origin, the fatherland. In Rakowski's opinion, the existence of these strong informal ties is characteristic of the "art of the informal" and of the Bulgan/Mongol model of development.

Przeplywy... is an interesting record of intense ongoing social changes. It is a compelling reading, especially for reviewers like me who were not previously acquainted with the economic and cultural context of Mongolia. However, the reader who, like me, is new to the Mongolian context, will be left with a certain sense of insatiety and with the feeling of having more questions than answers. This record of the author's repeated visits to Bulgan is a blink in the life of young Mongol businessmen; it concentrates on what is happening at the moment. This perspective means that the present being studied is not grounded enough in the historical context, especially in regard to specific figures and families.

The book contains a chapter on the history of the Mongol transformation. We learn a fair amount on the subject of the most recent history of Bulgan itself and of the economic transformations in the region. Yet the description of the activities of Torghut businessmen could have been undoubtedly enriched by use of the biographic method. Taking into account, to a larger degree, the life history of the persons studied would have allowed for a better understanding of their present situation as creators of the new economic system and of the basis for the present "art of the informal." To what degree, for instance, are ties from communist times still in use? The text suggests that the official authorities are personally connected with the former system, which after all is not surprising.

Interviewing members of various generations would also have been extremely valuable, as it would have allowed for analysis of both family ties and of how the new methods of doing business were formed: probably partly in opposition and partly in symbiosis with elements of the former system, combined with ancient local tradition. At the same time, the majority of the research material presented in the book describes celebrations, either in public institutions or those connected with rites, professions, the meetings of a school class or a local club, and even family celebrations or joint travels between cities. 
Rakowski shows that the activeness of the Bulgan businessmen is deeply grounded in social networks, chiefly those connected with the expanded family but also those involving strong ties between peers who attended the same school class. At certain places in the book the links between contemporary business, social activity, the Lamaist (Tibetan Buddhism) religion, and traditional customs are mentioned. The latter are chiefly customs connected with herding and the life cycle. The book's passages on these traditions appear almost incidentally, though. The author consciously seems to abandon a deeper analysis of this topic, perhaps on account of the fact that the traditional kin and custom structure connected with herding has already been described in considerable detail by other, earlier scholars, including Polish ones. However, leaving this body of knowledge aside means that the picture presented seems incomplete. One of the few rituals of a religious nature to have been noted is the custom of paying homage to the local mountain, which is considered to be the mother of the Torghut tribe a custom Rakowski seems to suggest was somehow “invented” by the leaders of Torghut society. It is, as Rakowski writes, a method of strengthening ties with the local fatherland (caring for nutag) for a society functioning in increasingly more globalised conditions and being still "on the road." It is hard to believe, however, that these rituals, which we learn are supported by the clergy, are entirely new and unconnected to tradition (perhaps they were discouraged or repressed during communist times).

The topic of the rites in honour of the mountain, with its ritual feeding, is unusually interesting. Lack of familiarity with the cultural context of Mongolia does not allow me to speculate in greater detail, but it appears that the interpretation could be taken further - that the rite could be an expression of grief connected with the loss of closeness and permanent presence in the native land (feeding the mountain as a fulfilment or symbolic maintenance of ties). In the 1970s, Mróz quoted one of his interlocutors, who said that "herders don't like to move" (1977: 162). The passage to a new means of life, which was partially imposed by the state policy of "de-animaling," must have been a disrupting or perhaps even a traumatic change, with which the herders-students-businessmen attempt to deal in various ways. An intriguing passage on the cyclical returns to family pastures of people not directly involved in herding would seem to encourage further study in this direction. During these cyclical returns, women who study or work as teachers or saleswomen wear traditional clothing and make dairy products, as if transforming themselves briefly into traditional shepherds. In the same context, one of Rakowski's interlocutors 
weeps when looking at photos from her homeland, saying that "Bulgan is always the same; always wonderful Bulgan." It would seem that the events described and statements quoted allow us to see here a deep need for communication with a certain unchanging "core" of the Torghut way of life.

This motif also raises the question of whether in reality we are dealing, as Rakowski writes, with a post-pastoral society, or whether the structure of this seemly changeable and continually moving society is still that of a pastoral society, although a weaker and less economically significant one than previously. Perhaps, to a certain degree, its "post-pastoralness" is expressed in the fact that the cyclical society's departures and returns to Bulgan, with the long and arduous journeys described by Rakowski, are analogous to the society's pendulum movement between winter and summer pastures?

These questions incline the reader to the conclusion that the book lacks a view of the structure of Torghut society and its place in the state organism of Mongolia. A "view from afar" - not entirely in the sense that Claude Lévi-Strauss meant it, but in the sense of paying attention to objectively existing dependences between specific elements of the social structure - would be useful. Such a view, which would be at least temporarily disconnected from "present history," would allow Rakowski to give a fuller answer to questions about the relation between the state and informal elements, that is, the ties created by the new Bulgan business sector. Rakowski devotes considerable space to these relations. As he writes, informal organisations sometimes cooperate, sometimes "replace," and sometimes "duplicate" the state institutions. He interestingly shows the interpenetration of these structures, for instance, in the case of a preschool, which functions thanks to the generous subsidies of businessmen (who are honoured during a special ceremony), or in the case of building a road. On the other hand, it is also noticeable that in many respects businessmen's associations play a role comparable to that of the state in such matters as, for instance, founding parks or organising important ceremonies. The author also mentions a certain element of rivalry between the state authorities and the informal authority formed by businessmen and social activists, although this motif is not developed. Perhaps Rakowski's unusually thought-provoking point that state positions are "traditionally" held by members of one of the Torghut groups, the Wangijn, which is considered rather lower in the hierarchy, while most of the businessmen he describes belong to the Bejlijn group, would be worth pursuing. 
It would seem that the traditional division of tasks among specific branches of the Torghut group means that the group of "informal businessmen" and social activists engage in a sort of game with the public sector, which is basically represented by another group, and one considered to be lower in the group hierarchy. The game can take the form of cooperation, exchange, or rivalry, or it can have an ambivalent nature, as Rakowski describes. However, Rakowski seems solely to touch on the theme of the objective social structure of the society he is studying, and he does not write much about internal and inter-ethnic relations either (e.g., about the sizeable Kazakh minority, which is traditionally agricultural). Rakowski uses various theoretical concepts which seem interesting but do not appear to be fully operationalised or consistently applied (for instance, the socialtechnical system).

The book Prreplymy... is part of the stream of criticism on the imposition of Western models of development and top-down modernisation, which often determine how the social worlds of non-European countries are understood (as in the anthropology of development or postcolonial studies). Rakowski correctly condemns the mechanisms of transferring such categories as civil society onto completely different social conditions, with the result that completely unsuitable development programmes are created. He mentions examples where the strong, informal ties of Mongolia have been described as corruption, nepotism, or even ties of a mafia nature. (He admits, however, that within the framework of the kin and acquaintanceship networks it sometimes happens that there are unreciprocated services, delays in payment, or even violence, and thus there are certain risks.) Such a mechanical application of Western categories is also visible in the sociological literature concerning Poland, for instance, in the context of Europeanisation and the complex "immaturity" of Polish democracy. In the last decade, a number of works have appeared which are critical of these concepts and condemn imitative thinking about progress and the necessity of a passive adaptation to the Western system. The works of Tomasz Zarycki on centre-periphery relations are especially pertinent (compare, e.g., Zarycki 2009, 2013; see also Sztandar-Sztanderska 2016; Zielieńska 2015).

We come then to the last question, which is especially important and concerns the axiological side of the book. There is no doubt that Rakowski's evaluation of the phenomenon he studies - economic development based on an informal social network - is very positive, although he is also aware of the potential dangers. The motif of praise for informal ways of cooper- 
ating and managing on one's own links Przptywy... with the author's earlier book Łowcy, zbieracze, praktycy niemocy. Etnografia człowieka zdegradowanego (Hunters, gatherers, practitioners of powerlessness: An ethnography of the degraded human), which concerns ways of dealing with a situation of poverty and exclusion in Poland after the transformation.

However, while the previous work primarily described those who found themselves on the bottom rung of the social ladder after the economic "shock therapy" in post-transition Poland, the book on the Torghuts describes above all those who have come out on top: those who have assumed the role of economic and social leaders in the said town and region. We do not know the perspective of those inhabitants of the Bulgan sum who did not manage to grasp that "wind steed" of success which is repeatedly mentioned in descriptions of the society (e.g., they are still engaged in herding as their main occupation). This does not mean, though, that Rakowski's positive opinion is not apt (it is hard for me to say). Perhaps in the Torghut system, thanks to the solidarity of family and peer groups, there are no groups condemned to degradation, exclusion, and extreme poverty - in contrast to the countries where the neoliberal version of capitalism has made itself at home. Nevertheless, we are undoubtedly not dealing with an egalitarian system, as one of the quotes placed at the beginning of the book - Marcin Król's statement on the need to "reclaim the idea of equality in some sensible form" in liberal democracies - would seem to suggest. What emerges from the ethnographical description in the book is rather a picture of a highly hierarchical arrangement which is perhaps not at all as dynamic and fluid as it would appear. Furthermore, the opposition between the Mongol "art of the informal" and the formalised societies of the West, which emerges as if between the lines, is not as sharp as Rakowski seems to indicate. The contributions of numerous scholars, from Pierre Bourdieu on, as well as anthropologists such as Janine Wedel, have shown the large role played by informal hidden relations in Western social systems. The anthropology of the success of Torghut businessmen is undoubtedly an interesting case of a non-schematic road to capitalist development. But if we were somehow to model our way of development on societies such as the Mongol one, it would be worthwhile first to look at them not only from the inside but also from a certain distance.

Transl. Michelle Granas 
Bibliography:

/// Mróz L. 1977. "Rytm torguckiego koczowania," Etnografia Polska, vol. 21(1), pp. 137-153.

/// Rakowski T. 2018. Przeptywy, wspótdziatania, kregi możliwego. Antropologia powodz̨enia, IEAK UW, Fundacja Terytoria Książki.

/// Sztandar-Sztanderska K. 2016. Obywatel spotyka państwo. O urzędach pracy jako biurokracji pierwszego kontaktu, Wydawnictwo Naukowe Scholar.

/// Zarycki T. 2009. Peryferie. O nowych wjeciach zależności centro-peryferyjnych, Wydawnictwo Naukowe Scholar.

/// Zarycki T. 2013. Ideologies of Eastness in Central and Eastern Europe, Routledge.

/// Zieleńska M. 2015. Mechanizmy reprodukcji $i$ zmiany w administracji publicznej na przykładzie wdrażania otwartej metody koordynacji, Wydawnictwo Naukowe Scholar.

/// Aleksandra Bilewicz - works at the Institute of Rural and Agricultural Development, Polish Academy of Sciences. Her research interests include social history of cooperatives, alternative food networks, deagrarianisation and repeasantisation. She has recently published "Beyond the modernization paradigm: Elements of food sovereignty discourse in farmer protests and alternative food networks in Poland," an article in Sociologia Ruralis.

ORCID: https://orcid.org/0000-0003-1133-1270

Email: ambilewicz@gmail.com 